\title{
PENANGGULANGAN STUNTING DAN PEMBERIAN ASUPAN NUTRISI DENGAN KEJADIAN STATUS GIZI PADA ANAK USIA 0-5 TAHUN
}

\author{
Ana Samiatul Milah ${ }^{1}$, Dini Nurbaeti Zen ${ }^{2}$, Nina Rosdiana ${ }^{3}$ \\ anamilah.fikesunigal82@gmail.com
}

${ }^{1,2,3}$ Fakultas Ilmu Kesehatan Universitas Galuh Ciamis

\begin{abstract}
ABSTRAK
Stunting adalah kurang gizi kronis yang disebabkan oleh kurangnya asupan nutrisi (Karbohidrat,Protein, vitamin, mineral, lemak) dalam waktu yang cukup lama, sehingga mengakibatkan gangguan pertumbuhan pada anak dalam usia pertumbuhan yakni tinggi badan anak menjadi lebih rendah atau pendek dari standar usianya. Pola asuh yang benar bisa ditempuh dengan memberikan perhatian yang penuh serta kasih sayang pada anak, memberinya waktu yang cukup untuk menikmati kebersamaan dengan seluruh anggota keluarga. Kejadian ini terjadi di Kabupaten ciamis yang kami teliti pada bulan periode Februari - Juli Tahun 2019. Penelitian ini bertujuan untuk mendapatkan Penanggulangan Stunting dan pemberian asupan nutrisi dengan kejadian status gizi pada anak usia 0-5 tahun di desa baregbeg kabupaten ciamis tahun 2019. Metode yang digunakan dalam penelitian ini adalah dengan metode penelitian deskriptif. Sampel yang digunakan adalah semua ibu yang memiliki balita 0-5 tahun di Desa Baregbeg Kecamatan Baregbeg Kabupaten ciamis sebanyak 74 orang dengan menggunakan teknik simple random sampling.Hasil penelitian ini menunjukan diantaranya status gizi balita adalah kategori gizi kurang sebanyak 43 orang $(58,1 \%)$, kebiasaan pemberian makan kategori cukup sebanyak 58 orang $(91,9 \%)$, kebiasaan pengasuhan kategori kurang 35 responden $(47,4 \%)$, kebiasaan kebersihan kategori cukup sebanyak 39 orang $(52,7 \%)$, kebiasaan pelayanan kesehatan kategori cukup sebanyak 38 orang $(51,3 \%)$. Dari hasil penelitian ini dapat disimpulkan bahwa angka status gizi di desa Baregbeg Kecamatan Baregbeg Kabupaten Ciamis tahun 2019 berada dalam kategori kurang sebanyak 43 orang $(58,1 \%)$. Keimpulan, Dari pengetahuan tentang hasil penelitian ini diharapkan terjadinya Suatu peningkatan peran dan fungsi ibu yang sebenarnya dalam pola pengasuhan balita agar angka status gizi yang diharapkan meningkat menjadi lebih baik demi terciptanya generasi yang lebih baik untuk kemajuan bangsa dan negara Indonesia.
\end{abstract}

\section{Kata Kunci : : Stunting, Asupan Nutrisi, Status Gizi Anak}

\section{ABSTRACT}

Stunting is a chronic malnutrition caused by a lack of nutrient intake (Carbohydrates, Proteins, vitamins, minerals, fats) in a long time, resulting in growth disorders in children of growth age ie the child's height becomes lower or shorter than the standard age. The right parenting can be pursued by giving full attention and affection to the child, giving him enough time to enjoy being with the whole family. This incident occurred in the District of Ciamis which we examined in the February - July period of 2019. This study aims to obtain Stunting Countermeasures and provide nutritional intake with the occurrence of nutritional status in children aged 0-5 years in the village of Baregbeg district of Ciamis in 2019. Methods used in this research is descriptive research method. The sample used was all mothers who have toddlers 0-5 years in Baregbeg Village, Baregbeg District, ciamis Regency as many as 74 people using simple random sampling techniques. The results of this study showed that among them the nutritional status of toddlers was the category of undernourished nutrition as many as 43 people (58.1\%), 58 people (91.9\%) of adequate feeding habits category, 35 respondents (47.4\%) parenting habits, 39 people $(52.7 \%)$ category enough hygiene habits, health service habits in the enough category 38 people (51.3\%). From the results of this study it can be concluded that the nutritional status figures in the village of Baregbeg, Baregbeg Subdistrict, Ciamis Regency in 2019 were in the poor category of 43 people (58.1\%). Conclusion, From the knowledge of the results of this study, it is 
expected that an increase in the actual role and function of mothers in the pattern of caring for children under five so that the expected nutritional status increases to be better for the creation of a better generation for the advancement of the nation and state of Indonesia.

\section{Keywords: Stunting, Nutrition, Child Nutritional Status}

\section{PENDAHULUAN \\ Latar Belakang}

Stunting adalah kurang gizi kronis yang disebabkan oleh kurangnya asupan nutrisi (Karbohidrat,Protein, vitamin, mineral, lemak) dalam waktu yang cukup lama, sehingga mengakibatkan gangguan pertumbuhan pada anak dalam usia pertumbuhan yakni tinggi badan anak menjadi lebih rendah atau pendek dari standar usianya ( Depkes RI ,2019). Prilaku (Pengetahuan, Sikap, Praktek). Pada Seorang Ibu yang mempunyai anak serta hidup dalam sebuah rumah tangga yang sekaligus merupakan bagian dari keluarga tersebut tidaklah lagi sebagai miniatur dari orang dewasa, melainkan anak harus dilihat sebagaimana layaknya seseorang individu yang utuh dan unik, dia mempunyai kebutuhan khusus yang berbeda dengan kebutuhan orang dewasa (Sujono, 2019).

Lingkungan keluarga memiliki peran cukup besar dalam membentuk kepribadian anak, karena dalam keluarga anak yang pertama kali mengenal dunia ini. Anak sering mencontoh semua prilaku yang ia lihat terutama di lingkungan keluarga karena memang di dalam keluargalah anak pertama kali mengenal pendidikan secara utuh.

Pola asuh dalam keluarga yang penuh kasih sayang dan pendidikan tentang nilai-nilai kehidupan, sosial, dan agama yang diberikan merupakan faktor yang kondusif untuk mempersiapkan anak untuk menjadi pribadi dan anggota masyarakat yang sehat ( Dari Faktor Psikologi). Menurut Yusuf (2019) yang dimaksud pola asuh adalah cara, bentuk atau strategi dalam pendidikan keluarga yang diakukan oleh orang tua kepada anak-anaknya. Pola dengan memberikan rasa kasih sayang dari orang tua memegang peranan cukup penting dalam memberikan standar prilaku dan sumber motivasi kepada anak untuk memenuhi peraturan tersebut.

Faktor hygiene dan sanitasi merupakan masalah penyebab terjadinya masalah kesehatan serta yaitu pengadaan sumber air bersih, jamban keluarga, serta perilaku cuci tangan dengan sabun dimana menurut penelitian Curtis (2005) menyebutkan bahwa perilaku cuci tangan dengan sabun pada saat yang tepat dapat mengurangi peluang terkena diare sampai $47 \%$, yang diikuti oleh fasilitas sanitasi sebesar $38 \%$. Faktor-faktor yang mempengaruhi terjadinya diare secara langsung adalah perilaku cuci tangan ibu balita, hygiene dan sanitasi serta keadaan status gizi balita. Perilaku ini semestinya ditempatkan pada jajaran paling atas sebagai program kesehatan masyarakat di Puskesmas dan dapat diberikan penyuluhan dalam bentuk Promosi Kesehatan, dimana fungsi puskesmas sebagai layanan kesehatan formal yang paling dekat dengan masyarakat harus perlu mendapatkan peran yang lebih besar, untuk dapat menjangkau masyarakat dengan pendekatan KEIM (Komunikasi, Edukasi, Informasi dan Motivasi) guna memberikan informasi dan mengubah perilaku bersih. Puskesmas menjadi sangat penting artinya peran preventif semestinya mendapat porsi lebih besar dalam mengatur anggaran yang ada sehingga dapat mengkomunikasikan pentingnya perilaku bersih secara lebih baik serta mulai memberikan lebih banyak peran pada sektor kesehatan masyarakat agar bisa mengkomunikasikan perilaku bersih guna mencegah penyakit-penyakit yang berkaitan dengan lingkungan yang ada di sekitarnya (Diah, 2010).

Masih tingginya angka prevalensi gizi kurang merupakan bukti belum terselenggaranya secara optimal Penanggulangan masalah gizi pada masyarakat. Berbagai upaya untuk mengatasi masalah gizi tersebut tidak terlepas dari kebijakan dan strategi pemerintah dalam meningkatkan kesehatan masyarakat. Pendidikan kesehatan melalui penyuluhan dengan Pendekatan KEIM (Komunikasi, Edukasi, Informasi dan Motivasi) yang dapat merupakan salah satu program yang diselenggarakan oleh 
pemerintah dalam meningkatkan kesadaran gizi dalam upaya meningkatkan status gizi masyarakat terutama pada ibu, yang mempunyai bayi dan balita, serta usia produktif.

Perbaikan status gizi masyarakat merupakan fokus prioritas poin kedua dalam kerangka kebijakan pembangunan kesehatan sebagaimana yang tertuang dalam Rencana Pembangunan Jangka Menengah (RPJM) bidang kesehatan tahun 2010-2015 dan yang ada dalam Millenium Develovmen Goal( MDG'S) rencana tahun 2015 pun masalah gizi masih menjadi fokus masalah kesehatan pemenuhan nutrisi pada balita Khususnya. Salah satu upaya untuk memperbaiki status gizi masyarakat yaitu dengan cara peningkatan pelayanan gizi dan masyarakat melalui pembinaan gizi masyarakat yaitu melalui program KADARZI (Sarjunani, 2015).

Penanggulangan masalah gizi di Provinsi Jawa Barat, upaya yang dilakukan Dinas Kesehatan Provinsi Jawa Barat saat ini meliputi upaya jangka pendek, dengan melakukan pelacakan kasus gizi buruk di setiap kabupaten dan kota. Jika ditemukan kasus gizi buruk segera dirujuk ke rumah sakit umum kelas III dengan biaya gratis bagi masyarakat miskin. Selain itu juga dilakukan dengan peningkatan kualitas sumber daya manusia serta pelatihan bagi petugas tenaga Gizi ( Kesehatan) (DinKes Prop. Jawa Barat, 2011).

Desa Baregbeg Kecamatan Baregbeg Kabupaten Ciamis Tahun 2019 Periode bulan September - Oktober terdapat 24 orang balita yang mengalami gizi kurang dan 1 orang balita mengalami gizi buruk dari jumlah balita keseluruhan sebanyak 920 orang. Pada Tahun 2011 yang mengalami gizi kurang sebanyak 77 orang dan 2 orang gizi buruk dari 989 orang balita, salah satu penyebab terjadinya gizi buruk yang terjadi adalah karena perilaku kesehatan yang kurang baik dan asupan nutrisi/gizi yang kurang terpenuhi.

Hasil studi pendahuluan di Desa Baregbeg Kecamatan Baregbeg Kabupaten Ciamis Periode bulan Februari sampai Maret dengan Tahun 2019 melalui wawancara yang dilaksanakan terhadap 10 orang ibu yang memiliki anak usia 0-5 tahun mengenai perilaku ibu tentang perilaku dan kebiasaan pemberian makan
(Asupan Nutrisi) seperti menerapkan pola makan gizi seimbang (Sumber zat makanan terdiri dari Karbohidrat, Protein,Vitamin, Mineral, lemak), perilaku dan kebiasaan Pola pengasuhan seperti memperhatikan anak pada saat bermain, perilaku dan kebiasaan kebersihan seperti membiasakan anak untuk mencuci kaki sebelum tidur dan kebiasaan membawa ke tempat pelayanan kesehatan seperti ibu selalu membawa anak ke posyandu pada setiap kegiatan posyandu berlangsung dilaksanakan setiap 1 (ssatu) bulan sekali dapat diperoleh 8 orang $(80 \%)$ memiliki kebiasaan yang kurang baik dan sisanya sebanyak 2 orang (20\%) yang memiliki perilaku yang baik.

Berdasarkan latar belakang masalah tersebut di atas, maka perlu dilakukan penelitian dengan judul "Hasil Penanggulangan Stunting Dan pemberian asupan nutrisi dengan kejadian status gizi pada anak usia 0-5 Tahun di Desa Baregbeg Kecamatan Baregbeg Kabupaten Ciamis Tahun 2019”.

\section{METODE PENELITIAN}

Metode dalam Penelitian ini adalah penelitian deskriptif. Populasi dalam penelitian ini adalah semua ibu yang memiliki balita 0-5 tahun di Desa Baregbeg Kecamatan Baregbeg Kabupaten Ciamis sebanyak 284 orang. Pengambilan Sampel dalam penelitian ini adalah sebagian yang diambil dari keseluruhan objek yang diteliti dan dianggap mewakili seluruh populasi (Notoatmodjo, 2007).

Rumus yang digunakan mencari sampel adalah sebagai berikut :

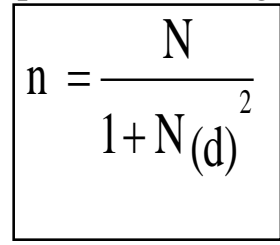

Keterangan :

$\mathrm{n}=$ Jumlah sampel

$\mathrm{N}=$ Besar populasi

$\mathrm{d}=$ Tingkat kepercayaan $(10 \%)$

$\mathrm{n}=\frac{284}{1+284(0,1)^{2}}$

$\mathrm{n}=\frac{284}{3,84}$

$\mathrm{n}=73,96 \approx 74$ 
Dalam penelitian ini digunakan teknik pengambilan sampel teknik simple random sampling yaitu pengambilan sampel dilakukan secara acak sehingga subjek dianggap sama untuk memperoleh kesempatan dipilih menjadi sampel tanpa perasaan ingin mengistimewakan satu atau beberapa subjek untuk dijadikan sampel. Metode pengambilan sampel acak sederhana yang dilakukan menggunakan teknik undian (Arikunto, 2006). Jadi jumlah sampel dalam penelitian ini adalah sebanyak 74 orang ibu yang memiliki balita 0-5 tahun.

Penelitian dilakukan di Desa

Baregbeg Kecamatan Manonjya Kabupaten Ciamis periode bulan September - Oktober 2019.

Variabel dalam penelitian ini Penanggulangan Stunting pada ibu dengan status gizi anak usia 0-5 tahun. Instrumen yang akan digunakan dalam penelitian ini yaitu kuesioner berupa lembar check list. Pertanyaan tertutup berisi identitas responden dan pertanyaan terbuka terdiri dari beberapa pertanyaan berkaitan dengan perilaku ibu yang mempunyai balita tentang status gizi, pemberian makan, pola asuh, kebersihan diri dan pelayanan kesehatan.

Pengumpulan Data Primer yang diperoleh melalui wawancara langsung dengan ibu yang memiliki anak usia 0-5 tahun yang ditetapkan menjadi responden dan berpedoman pada instrumen yang telah dipersiapkan.

Pengumpulan Data Sekunder yang diperoleh dari catatan dan laporan yang ada di Desa Baregbeg Kecamatan Baregbeg Kabupaten Ciamis untuk mendapatkan jumlah ibu yang memiliki balita. Pengumpulan data dilakukan oleh peneliti dengan dibantu 2 orang tenaga ahli gizi puskesmas, dan data yang telah terkumpul akan diolah secara deskriptif dan analitis serta disajikan dalam tabel distribusi frekuensi.

Agar instrumen valid dan reliabel maka sebelum digunakan sebagai alat ukur penelitian dilakukan uji validitas yaitu suatu indeks yang menunjukkan alat ukur itu benar-benar mengukur apa yang diukur, dan reliabilitas yaitu indeks yang menunjukkan sejauh mana suatu alat pengukur dapat dipercaya atau dapat diandalkan (Notoatmodjo, 2002

Analisis yang dilakukan adalah dengan menggunakan distribusi frekuensi dengan tujuan untuk mengetahui hasil Penanggulangan Stunting dan pemberian asupan nutrisi dengan kejadian status gizi pada anak usia 0-5 tahun.

kemudian selanjutnya dilakukan pengolahan hasil penelitian dengan cara menghitung persentase jawaban yang benar untuk setiap item pertanyaan dari seluruh responden dengan menggunakan rumus :

$X=\frac{Y}{N} X 100 \%$
Keterangan:

$\mathrm{X}=$ pengetahuan responden tentang bantuan hidup dasar.

$\mathrm{Y}=$ Jumlah alternatif jawaban yang benar.

$\mathrm{N}=$ Jumlah keseluruhan soal.

Alasan menggunakan rumus ini, karena jawaban setiap responden berbeda dan dihitung berdasarkan jumlah, kemudian interpretasi data hasil penelitian dikelompokkan dalam 3 kategori yaitu :
a. Baik : Apabila didapat hasil 76-100\%
b. Cukup : Apabila didapat hasil $56-75 \%$
c. Kurang
: Apabila didapat hasil (Arikunto, 2006).

\section{HASIL DAN PEMBAHASAN \\ HASIL \\ Status Gizi Balita}

Berdasarkan hasil penelitian secara deskriptif dengan menggunakan kuesioner yang dilakukan di Desa Baregbeg Kecamatan Baregbeg Kabupaten Ciamis Tahun 2019 mengenai status gizi balita diperoleh hasil sebagai berikut.

Distribusi Frekuensi Status Gizi Balita di Desa BaregbegKecamatan Baregbeg Kabupaten CiamisTahun 2019

\begin{tabular}{cccc}
\hline No & Kategori & f & $\%$ \\
& & & \\
\hline $\mathbf{1}$ & Gizi Buruk & 2 & 2,7 \\
$\mathbf{2}$ & Gizi Kurang & 43 & 58,1 \\
\hline
\end{tabular}




\begin{tabular}{cccc}
\hline $\mathbf{3}$ & Gizi Baik & 29 & 39,2 \\
$\mathbf{4}$ & Gizi Lebih & 0 & 0,0 \\
& Total & $\mathbf{7 4}$ & $\mathbf{1 0 0}$ \\
\hline
\end{tabular}

Dari tabel diatas dapat diketahui bahwa di Desa Baregbeg Kecamatan Baregbeg Kabupaten Ciamis Tahun 2019, balita dengan status gizi kurang merupakan persentase terbesar yaitu sebanyak 43 orang $(58,1 \%)$, balita dengan status gizi baik sebanyak 29 orang $(39,2 \%)$ dan balita yang dengan status gizi buruk sebanyak 2 orang $(2,7 \%)$.

\section{Penanggulangan Stunting}

\section{a. Kebiasaan Pemberian Makan} Berdasarkan hasil penelitian yang dilakukan di Desa Baregbeg Kecamatan Baregbeg Kabupaten Ciamis Tahun 2019 mengenai kebiasaan pemberian makan diperoleh hasil sebagai berikut.

Distribusi Frekuensi Kebiasaan Pemberian Makan di Desa Baregbeg Kecamatan BaregbegKabupaten Ciamis Tahun 2019

\begin{tabular}{clcc}
\hline No & Kategori & f & $\%$ \\
& & & \\
\hline $\mathbf{1}$ & Baik & 5 & 6,8 \\
$\mathbf{2}$ & Cukup & 68 & 91,9 \\
$\mathbf{3}$ & Kurang & 1 & 1,4 \\
& Total & $\mathbf{7 4}$ & $\mathbf{1 0 0}$ \\
\hline
\end{tabular}

Dari tabel di atas dapat diketahui bahwa di Desa Baregbeg Kecamatan Baregbeg Kabupaten Ciamis Tahun 2019, keluarga yang memiliki kebiasaan pemberian makan kategori cukup merupakan persentase terbesar yaitu sebanyak 68 orang $(91,9 \%)$.

\section{b. Kebiasaan Pengasuhan}

Berdasarkan hasil penelitian yang dilakukan di Desa Baregbeg Kecamatan Baregbeg Kabupaten Ciamis Tahun 2019 mengenai kebiasaan pengasuhan diperoleh hasil sebagai berikut.
Distribusi Frekuensi Kebiasaan Pengasuhan di Desa Baregbeg Kecamatan Baregbeg Kabupaten Ciamis Tahun 2019

\begin{tabular}{clcc}
\hline No & Kategori & f & $\%$ \\
& & & \\
\hline $\mathbf{1}$ & Baik & 9 & 12,2 \\
$\mathbf{2}$ & Cukup & 30 & 40,5 \\
$\mathbf{3}$ & Kurang & 35 & 47,4 \\
& Total & $\mathbf{7 4}$ & $\mathbf{1 0 0}$ \\
\hline
\end{tabular}

Dari tabel di atas dapat diketahui bahwa di Desa Baregbeg Kecamatan Baregbeg Kabupaten Ciamis Tahun 2019, keluarga yang memiliki kebiasaan pengasuhan dengan kategori kurang merupakan persentase terbesar yaitu sebanyak 35 orang $(47,4 \%)$.

\section{c. Kebiasaan Kebersihan}

Berdasarkan hasil penelitian yang dilakukan di Desa Baregbeg Kecamatan Baregbeg Kabupaten Ciamis Tahun 2019 mengenai kebiasaan kebersihan diperoleh hasil sebagai berikut.

Distribusi Frekuensi Kebiasaan Kebersihan di Desa Baregbeg Kecamatan Baregbeg Kabupaten Ciamis Tahun 2019

\begin{tabular}{clcc}
\hline No & Kategori & f & $\%$ \\
& & & \\
\hline $\mathbf{1}$ & Baik & 8 & 10,8 \\
$\mathbf{2}$ & Cukup & 39 & 52,7 \\
$\mathbf{3}$ & Kurang & 27 & 36,5 \\
& Total & $\mathbf{7 4}$ & $\mathbf{1 0 0}$ \\
\hline
\end{tabular}

Dari tabel di atas dapat diketahui bahwa di Desa Baregbeg Kecamatan Baregbeg Kabupaten Ciamis Tahun 2019, keluarga yang memiliki kebiasaan kebersihan dengan kategori cukup yaitu sebanyak 39 orang (52,7\%).

d. Kebiasaan Pelayanan Kesehatan

$$
\begin{array}{lr}
\text { Berdasarkan hasil penelitian } \\
\text { yang dilakukan Desa } & \text { Baregbeg } \\
\text { Kecamatan Baregbeg } & \text { Kabupaten } \\
\text { Ciamis Tahun 2019 mengenai } & \text { mesehatan } \\
\text { kebiasaan pelayanan } & \text { kesehan } \\
\text { diperoleh hasil sebagai berikut. }
\end{array}
$$

Distribusi Frekuensi Kebiasaan Pelayanan Kesehatan di Desa Baregbeg Kecamatan BaregbegKabupaten Ciamis Tahun 2019 


\begin{tabular}{clcc}
\hline No & Kategori & f & $\%$ \\
& & & \\
\hline $\mathbf{1}$ & Baik & 7 & 9,5 \\
$\mathbf{2}$ & Cukup & 38 & 51,3 \\
$\mathbf{3}$ & Kurang & 29 & 39,2 \\
& Total & $\mathbf{7 4}$ & $\mathbf{1 0 0}$ \\
\hline & Dari tabel & di & atas dapat diketahui
\end{tabular}

bahwa di Desa Baregbeg Kecamatan Baregbeg Kabupaten Ciamis Tahun 2019, keluarga yang memiliki kebiasaan terhadap pelayanan kesehatan dengan kategori cukup sebanyak 38 orang $(51,3 \%)$.

\section{PEMBAHASAN}

\section{Stunting}

Stunting adalah kurang gizi kronis yang disebabkan oleh kurangnya asupan nutrisi (Karbohidrat,Protein, vitamin, mineral, lemak) dalam waktu yang cukup lama, sehingga mengakibatkan gangguan pertumbuhan pada anak dalam usia pertumbuhan yakni tinggi badan anak menjadi lebih rendah atau pendek dari standar usianya. Stunting merupakan hambatan pertumbuh-an yang diakibatkan oleh selain kekurangan asupan zat gizi juga adanya masalah kesehat-an. Stunting adalah suatu proses yang ber-dampak pada perkembangan anak mulai dari tahap dini, yakni saat konsepsi hingga tahun ke-3 atau ke-4 kehidupan anak, di mana keadaan gizi ibu dan anak merupakan faktor penting dari pertumbuhan anak.3 Stunting pada usia dini ber-hubungan dengan kejadian kemunduran mental pada tingkat kecerdasan anak, perkembangan psikomotorik dan kemampuan motorik yang baik. Juga bisa menurunkan kemampuan kerja pada saat usia dewasa

\section{Status Gizi}

Berdasarkan hasil penelitian mengenai status gizi balita di Desa Baregbeg Kecamatan Baregbeg Kabupaten Ciamis Tahun 2019 frekuensi terbesar adalah termasuk kategori gizi kurang yaitu sebanyak 43 orang $(58,1 \%)$. Gizi merupakan salah satu kebutuhan hidup manusia yang erat kaitannya dengan kualitas fisik maupun mental manusia. Keadaan gizi meliputi proses penyediaan dan penggunaan gizi untuk pertumbuhan, perkembangan, dan pemeliharaan serta aktivitas. Keadaan kurang gizi dapat terjadi akibat ketidakseimbangan asupan zat-zat gizi, faktor penyakit pencernaan, absorpsi dan penyakit infeksi.

Masalah gizi merupakan masalah yang sangat kompleks dan mempunyai dimensi yang sangat luas, tidak hanya menyangkut aspek kesehatan tetapi juga meliputi masalah sosial, ekonomi, budaya, pola asuh, pendidikan, lingkungan dan perilaku. Mengingat penyebabnya sangat kompleks, pengolahan gizi buruk memerlukan kerjasama yang komprehensif dan semua pihak, bukan hanya oleh petugas medis, namun juga pihak orang tua, keluarga, pemuka agama dan pemerintah.

Hasil penelitian ini sejalan dengan pendapat dari Jaringan Informasi Pangan dan Gizi (2015) yang menyatakan bahwa gizi kurang merupakan salah satu masalah gizi utama pada balita Indonesia. Gangguan (masalah) gizi pada anak balita, dapat menyebabkan marasmus, kwashiorkor atau marasmik-kwashiorkor yang juga akan menyebabkan gangguan pertumbuhan pada anak usia sekolah. Gangguan ini akan menjadi serius bila tidak ditangani secara intensif. Pertumbuhan dapat dilihat dengan bebe-rapa indikator satus gizi. Secara umum terdapat 3 indikator yang bisa digunakan untuk meng-ukur pertumbuhan bayi dan anak, yaitu indikator berat badan menurut umur $(\mathrm{BB} / \mathrm{U})$, tinggi badan menurut umur $(\mathrm{TB} / \mathrm{U})$ dan berat badan menurut tinggi badan (BB/TB). Stunting merupakan salah satu masalah gizi yang diakibatkan oleh kekurangan zat gizi secara kronis. Hal ini ditunjukkan dengan indikator $\mathrm{TB} / \mathrm{U}$ dengan nilai skor-Z (Z-score) di bawah minus 2.

Dampak dari gangguan pada masa bayi dan anak, khususnya stunting dapat menyebabkan gangguan perkembangan kognitif dan meningkatnya risiko terhadap penyakit infeksi dan lebih lanjut kematian.1 
Stunting juga berhubungan dengan performa sekolah, bahkan, pada tingkat lanjut dapat menurunkan tingkat produktivitas di masa dewasa.

\section{Penanggulangan Stunting}

Usia 0-2 tahun atau usia bawah tiga tahun (batita) merupakan periode emas (golden age) untuk pertumbuhan dan perkembangan anak, karena pada masa tersebut terjadi pertumbuhan yang sangat pesat. Periode 1000 hari pertama sering disebut window of opportunities atau periode emas ini didasarkan pada kenyataan bahwa pada masa janin sampai anak usia dua tahun terjadi proses tumbuh-kembang yang sangat cepat dan tidak terjadi pada kelompok usia lain. Gagal tumbuh pada periode ini akan mempengaruhi status gizi dan kesehatan pada usia dewasa.2 Oleh karena itu perlu dilakukan upaya-upaya penanggulangan masalah stunting ini mengingat tingginya prevalensi stunting di Indonesia.

Hasil kajian terhadap jenis intervensi dalam rangka upaya pencegahan stunting pada anak batita diperoleh sebanyak 16 artikel. Ada 4 jenis intervensi dalam upaya penanggulangan masalah stunting pada anak batita, yaitu zat gizi tunggal, kombinasi 2-3 zat gizi, multi-zat-gzimikron dan zat gizi plus penambahan energi. Namun, dari Tabel 2 jenis zat gizi sebagai bahan intervensi yang paling banyak digunakan untuk peningkatan pertambahan panjang linier adalah mineral seng ( $\mathrm{Zn}$ ), zat besi $(\mathrm{Fe})$, serta kombinasi keduanya, seperti halnya vitamin A.

Intervensi dengan zat gizi tunggal (vitamin $\mathrm{A}, \mathrm{Zn}, \mathrm{Fe}$ ) atau kombinasi 2-3 jenis zat gizi memberikan hasil yang bervariasi terhadap peningkatan panjang badan. Intervensi dengan pemberian vitamin A15, pemberian $\mathrm{Zn}$ selama 6 bulan memberikan dampak peningkatan panjang badan anak batita secara signifikan.8,16 Sementara pada penelitian Thu BD et al., peningkatan panjang badan hanya terjadi pada bayi yang pada awalnya menderita stunting.12 Dijkhuizen et al. juga menemukan peningkatan petumbuhan linier hanya terjadi pada bayi yang menderita anemia.16 Rupanya, keadaan bayi yang pada awal intervensi menderita stunting atau anemia lebih responsif pada saat diberikan zat gizi dibandingkan yang normal. Mungkin hal ini juga yang menyebabkan perbedaan hasil intervensi, seperti yang terlihat pada penelitian Wasantwisut et al.21, Fahmida U dkk.8, Dijkhuizen et al.16, Thu BD et al.12, walau zat gizi yang diberikan sama $(\mathrm{Fe}+\mathrm{Zn})$. Penambahan zat gizi lain, seperti vitamin A dan vitamin $\mathrm{C}$, ternyata juga tidak selalu berefek positif (Tabel 3). Intervensi dengan memberikan multimicronutrient (MMN) pada bayi ternyata juga menunjukkan hasil yang bervariasi. Penelitian Untoro J dkk. serta Hop LT menunjukkan peningkatan panjang badan yang bermakna setelah 6 bulan intervensi.14,17 MMN ada yang disebut Taburia untuk di Indonesia atau sprinkle merupakan bahan intervensi untuk menanggulangi masalah defisiensi mikronutrien pada anak balita dan merupakan salah satu program secara nasional di Indonesia. Adanya perbedaan desain, dosis dan lama intervensi akan berpengaruh terhadap hasil outcome yang diukur. Kekuatan desain penelitian dalam tiap artikel bisa dilihat dari skor Jadad, nilai 5 menunjukkan pelaksanaan penelitian secara terbuka dikemukanan mulai awal perrekrutan sampel sampai selesai berakhirnya intervensi. Pada Tabel 9 terlihat intervensi yang dilakukan Hop LT dan Smuts et al. (pemberian multizat-gizi-mikro selama 6 bulan) mempunyai persamaan.17,18 Namun, hasil intervensi menunjukkan, selisih Z-score yang berbeda. Jumlah sampel dan kondisi awal sampel bisa menjadi salah satu faktor perbedaan.

Tabel 10 memperlihatkan, penelitian intervensi dalam upaya peningkatan panjang badan bayi dengan memberikan zat gizi mikro (Zn) dikombinasikan dengan zat gizi makro sumber karbohidrat serta 
penambahan multivitamin. Outcome dari intervensi ternyata tidak mampu meningkatkan panjang badan atau HAZ secara signifikan.

Terlepas dari tidak didapatkannya pertambahan panjang badan yang signifikan, tidak diragukan bahwa inetervensi zat gizi mikro memberikan keuntungan terhadap peningkatan status zat gizi mikro atau kesehatan bayi secara umum. Vitamin $\mathrm{A}$ dan $\mathrm{Fe}$ diketahui mempunyai peran terhadap tingkat imunitas anak, sedangkan $\mathrm{Zn}$ berperan dalam pertumbuhan anak.

Pertumbuhan anak merupakan produk dari multi-faktor, baik faktor gizi maupun lingkungan. Periode masa kehamilan hingga anak berusia 2 tahun dikatakan merupakan periode kritis atau periode sensitif karena bila terjadi masalah pada periode ini dampaknya tidak dapat diperbaiki atau tidak bisa tumbuh secara optimal.

Secara umum dapat

disimpulkan bahwa intervensi pada bayi dalam rangka penanggulangan masalah stunting dengan memberikan zat gizi tunggal, kombinasi 2-3 zat gizi atau multi-zat-gizi-mikro telah banyak dilakukan dan dampaknya, walau sedikit, bisa mencegah anak batita menjadi stunting. Selain suplementasi zat gizi mikro, seperti vitamin $\mathrm{A}, \mathrm{Zn}$, $\mathrm{Fe}$, dan iodium, peningkatan ASI eksklusif, makanan pendamping ASI serta konseling semasa ibu hamil, harus juga terus dilakukan. Maka dari itu suatu langkah dan pendekatan yang di dapat dari hasil penelitian adalah :

\section{a. Kebiasaan Pemberian Makan}

Berdasarkan hasil penelitian mengenai perilaku positif di Desa Baregbeg Kecamatan Baregbeg Kabupaten Ciamis Tahun 2019 dalam kebiasaan pemberian makan frekuensi terbesar adalah termasuk kategori cukup yaitu sebanyak 58 orang $(91,9 \%)$. Kebiasaan memberi makan anak-anak kecil berusia di atas 6 bulan dengan berbagai variasi makanan dalam porsi kecil setiap hari, pemberian makan secara aktif, pemberian makan selama sakit dan penyembuhan serta menangani anak yang memiliki selera makan yang rendah mencerminkan interaksi ibu dengan anak akan berhubungan positif dengan keadaan gizi anak. Ini berarti bahwa anak usia 0-5 tahun yang status gizinya tidak baik mempunyai peluang bahwa keluarga tersebut memiliki kebiasaan pemberian makan tidak baik.

Asupan makanan merupakan penyebab langsung terhadap status gizi anak balita, selain infeksi penyakit. Tidak baiknya keluarga dalam memberikan makanan pada anak usia balita tersebut dapat disebabkan dalam penyediaan makanan yang sarat gizi mengalami keterbatasan. Penelitian Kartika (2006) tentang pola makanan anak usia 6-18 bulan, ditemukan 80\% anak mempunyai pola makan yang tidak lengkap, sehingga menyebabkan status gizi tidak baik. Penyebab lainnya adalah kesibukan si ibu atau pengasuh lainnya dalam mencari nafkah seperti bekerja di ladang sehingga kurang waktu dalam hal pemberian makan yang baik dan kurangnya waktu untuk menyiapkan makanan dengan lengkap. Di samping itu status gizi tidak baik tersebut kemungkinan dapat disebabkan adanya infeksi penyakit pada anak balita. Infeksi penyakit dapat terjadi pada anak dapat dikarenakan kurangnya asupan makanan yang dapat menyebabkan daya tahan tubuh menjadi rendah, sehingga mudah terkena infeksi.

\section{b. Kebiasaan Pengasuhan}

Berdasarkan hasil penelitian mengenai perilaku positif di Desa Baregbeg Kecamatan Baregbeg Kabupaten Ciamis Tahun 2019 dalam kebiasaan pengasuhan frekuensi terbesar adalah termasuk kategori kurang yaitu sebanyak 35 orang (47,3\%). Pola asuh yang baik merupakan hasil dan adanya interaksi positif antara anak dengan pengasuh utama yang dapat membantu perkembangan emosi dan psikologis anak.

Dengan pola asuh yang baik dan benar termasuk dalam memberikan perhatian dapat menciptakan perkembangan anak yang normal. Ini berarti bahwa anak usia 0-5 tahun yang memiliki status gizi tidak baik mempunyai peluang pada keluarga yang menerapkan kebiasaan pola asuh tidak 
baik dibandingkan dengan anak pada keluarga dengan pola asuh yang baik. Jadi dengan melakukan pola pengasuhan pada anak secara baik termasuk memberi perhatian dalam kebutuhan makan dan menjaga kesehatan anak, dan berpengaruh terhadap status gizinya. Perlu diketahui bahwa dalam hal pengasuhan anak, ibu adalah orang yang paling banyak terlibat, sehingga pengaruhnya sangat besar pada perkembangan anak.

\section{c. Kebiasaan Kebersihan}

Berdasarkan hasil penelitian mengenai perilaku positif di Desa Baregbeg Kecamatan Baregbeg Kabupaten Ciamis Tahun 2019 dalam kebiasaan kebersihan memiliki frekuensi terbesar adalah kategori cukup yaitu sebanyak 39 orang $(52,7 \%)$. Kebersihan diri yang menyangkut kebersihan tubuh, kebersihan makanan dan lingkungan berperan dalam pemeliharaan kesehatan anak serta mencegah penyakit infeksi yang pada gilirannya dapat mempengaruhi status gizi anak. Ini berarti bahwa anak usia 0-5 tahun yang memiliki status gizi tidak baik mempunyai peluang pada keluarga yang menerapkan kebiasaan kebersihan diri tidak baik dibandingkan dengan anak pada keluarga dengan kebersihan diri yang baik.

Kebersihan diri yang tidak baik akan memudahkan timbulnya penyakit infeksi pada anak, apalagi bila asupan makanan bagi anak kurang karena kemiskinan. Kebersihan yang tidak baik khususnya yang menyangkut lingkungan seperti pembuangan tinja maupun penyediaan air bersih yang kurang memadai sangat berpotensi timbulnya penyakit pada anak. Penelitian Tarigan (2003) menunjukkan bahwa prevalensi gizi kurang pada anak dengan tempat buang air besar buruk, meningkat dan $36,4 \%$ menjadi $41,6 \%$. Pada umumnya kebiasaan kebersihan ibu atau pengasuh lainnya masih belum sesuai dengan prinsip-prinsip higiene dan sanitasi lingkungan, hal ini dapat juga dilihat pada saat observasi lingkungan responden, sehingga akan menjadi faktor penyebab timbulnya penyakit infeksi pada anak, karena pada umumnya anak usia 0-5 tahun sudah dibiarkan bermain sendiri. Demikian juga disebutkan bahwa peluang status gizi kurang pada anak dengan sumber air minum buruk 1,7 kali lebih tinggi dibanding anak dengan sumber air minum baik.

\section{d. Kebiasaan Pelayanan Kesehatan}

Berdasarkan hasil penelitian mengenai perilaku positif di Desa Baregbeg Kecamatan Baregbeg Kabupaten Ciamis Tahun 2019 dalam kebiasaan mendapatkan pelayanan kesehatan memiliki frekuensi terbesar adalah kategori cukup yaitu sebanyak 38 orang $(51,4 \%)$. Kebiasaan mengakses pelayanan kesehatan bagi anak seperti memberikan imunisasi, pengobatan penyakit dan bantuan tenaga profesional sangat berperan dalam menjaga kesehatan anak. Ini berarti bahwa anak usia 0-5 tahun yang memiliki status gizi tidak baik mempunyai peluang terdapat pada keluarga yang pelayanan kesehatannya tidak baik dibandingkan dengan anak pada keluarga yang mendapatkan pelayanan kesehatannya baik. Mudah tidaknya keluarga untuk memperoleh kemudahan tentang kesehatan, tersedianya dan kemudahan sarana kesehatan termasuk sumber daya manusianya serta kemampuan keluarga.

\section{KESIMPULAN DAN SARAN}

\section{KESIMPULAN}

Berdasarkan hasil penelitian dan pembahasan yang telah dilakukan mengenai hasil "Penanggulangan Stunting " dan asupan nutrisi terhadap status gizi anak usia 0-5 tahun di Desa Baregbeg Kecamatan Baregbeg Kabupaten Ciamis Tahun 2019 dapat ditarik kesimpulan Ada 4 jenis intervensi dalam upaya penanggulangan stunting pada anak batita, yaitu pemberian zat gizi tunggal, kombinasi 2-3 zat gizi, multi-zat-gizi-mikro, dan zat gizi plus penambahan energi (zat gizi makro).

Intervensi pada bayi dengan memberikan zat gizi tunggal, kombinasi 23 zat gizi atau multi-zat-gizi-mikro mempunyai hasil yang tidak konklusif bervariasi terhadap peningkatan panjang 
badan atau pertumbuhan bayi atau anak. Yang dapat di tindaklanjuti sebagai berikut:

Status gizi balita di Desa Baregbeg Kecamatan Baregbeg Kabupaten Ciamis Tahun 2019 sebagian besar termasuk kategori gizi kurang yaitu sebanyak 43 orang $(58,1 \%)$.

Kebiasaan Pemberian makan di Desa Baregbeg Kecamatan Baregbeg Kabupaten Ciamis Tahun 2019 sebagian besar termasuk kategori cukup yaitu sebanyak 68 orang $(91,9 \%)$.

Kebiasaan pengasuhan di Desa Baregbeg Kecamatan Baregbeg Kabupaten Ciamis Tahun 2019 sebagian besar termasuk kategori kurang yaitu sebanyak 35 orang $(47,4 \%)$.

Kebiasaan Kebersihan di Desa Baregbeg Kecamatan Baregbeg Kabupaten Ciamis Tahun 2019 memiliki persentase terbesar dengan kategori cukup yaitu sebanyak 39 orang $(52,7 \%)$.

Kebiasaan pelayanan kesehatan di Desa Baregbeg Kecamatan Baregbeg Kabupaten Ciamis Tahun 2019 sebagian besar termasuk kategori cukup yaitu sebanyak 38 orang $(51,3 \%)$.

\section{SARAN}

Intervensi zat gizi tetap harus mempertimbangkan dosis, frekuensi pemberian serta prioritas terhadap kelompok rawan, seperti batita yang mempunyai masalah defisiensi, baik zat gizi makro maupun zat gizi mikro. Upaya penanggulangan stunting harus dimulai sejak masa periode ibu hamil, maka dari hasil penelitian ini kami memberikan saran utuk :

Bagi Tenaga Kesehatan Perlu mensosialisasikan Penanggulangan Stunting ibu oleh tenaga kesehatan khususnya bidan melalui berbagai kegiatan di Posyandu tentang pola pengasuhan, kebersihan diri, kebiasaan dalam pemberian makanan dan pelayanan kesehatan anak usia 0-5 tahun pada keluarga yang status gizi anaknya tidak baik dengan pendekatan KIEM (Komunikasi, Edukasi, Informasi dan Motivasi) kepada ibu yang mempunyai balita.

Bagi Ibu Yang Mempunyai Balita 0-5 Tahun Perlu mengembangkan dan memperhatiikan tentang masalah kesehatan dengan konsep perilaku ibu yang positif terhadap peningkatan kualitas gizi balita dalam keluarga dengan penyelenggaran lim azat gizi yang diperlukan oleh tubuh manuasia yaitu

Karbohidrat,Protein,Vitamin,Mineral,L emak.

Bagi Tenaga Kesehatan Melalui Program Promosi Kesehatan yaitu dengan melakukan pendekatan pada masyarakat yaitu dengan memberikan informasi mengenai KADARGZI dan sehingga mampu memberikan efek positif terhadap perkembangan Pengetahuan pada Ibu yang mempunyai Balita mengenai pendidikan penanganan masalah gizi pada balita harus lebih di perhatikan lagi,Karena Walau bagaimanapun Kesehatan Balita sangat ditentukan oleh apa yang di konsumsinya.Maka Status Gizi, Kesehatan, Penyakit yang akan ditimbulkan,Tingkat Kecerdasan dan daya tahan tubuh ditentukan oleh gizi yang di konsumsi sehari - hari.

\section{DAFTAR PUSTAKA}

Almatsier S. (2010). Prinsip Dasar Ilmu Gizi. Jakarta : Gramedia Pustaka Utama.

Arikunto S. (2002). Prosedur Penelitian Suatu Pendekatan Praktek. Rineka Cipta : Jakarta

Baliwati, YF, Khomsan, A dan Dwiriani, CM. (2006). Pengantar Pandan dan Gizi, Cetakan II. Penebar Swadaya : Jakarta

Child Survival Collaboration and Resources , CM.(2006). Pengantar Ilmu gizi dan Pangan cetakan II, Jakarta : Penebar Swadaya.

CORE. (2003). Penanggulangan Stunting \&Health, Suatu Pendekatan Perubahan Perilaku\&Masalah gizi pada Masyarakat.Deterjemahkan oleh PCI - Indonesia. Jakarta : 2004.

Curtis. (2005). Komunikasi Profesional .PT. Remaja Rosdakarya Bandung. 
Departemen Kesehatan RI.(2019). Stunting, Klasifikasi Status Gizi Anak Bawah Lima Tahun( BALILA), Jakarta : Direktorat Bina Kesehatan Masyarakat. , (2010) Pedoman Pengelolaan Makanan pendamping ASI (MP -ASI). Jakarta : Direktorat Bina Gizi Masyarakat.

Diah.2015 .Peningkatan Motivasi dan Keaktifan .Surakarta : FKIP UMS.

Gunarsa, SD.(2003).Psikologi Dalam Pendidikan Anak.Jakarta: PT.Gunung Mulia.

Hadi,Abdul.(2010)Psikologi dalam perkembangan dan pendidikan : Alfabeta.

Hidayat A. (2007). Pengantar Konsep Keperawatan anak.

JIPG.(2005).Gizi Baik Modal Kehidupan Manusia "Jaringan Informasi Pangan dan Gizi, Volume XLI, No.2 Jakarta : Direktorat Gizi Masyarakat.

Lisa, (2015). " Pola Pemberian Makanan Anak (6-18) Bulan dan Hubungannya dengan Pertumbuhan dan perkembangan Anak Pada Keluarga Miskin dan tidak Miskin”. Penelitian Gizi Makanan, Bogor;Puslitbang Gizi.

Muzaham, F., (2005). Memperkenalkan Sosiologi Kesehatan . Jakarta : Penerbit Universitas ( UI Press).

Nadia.(2019). Hubungan Antara Pengetahuan Gizi Ibu Dengan status Gizi anak Sekolah Taman kanak - Kanak. Universitas Gajah Mada.

Nurpudji, (2015), “Kasus Gizi Buruk" Jakarta : Indonesia Nutrition .

Notoatmodjo, S (2007). Ilmu kesehatan Masyarakat. Jakarta: Penerbit PT . Rineka Cipta.
Pauline, dkk. (2003). Penanggulangan Stunting \& Health, Suatu Pendekatan Perubahan Perilaku\&Pos Gizi.

Santoso, S, (2001)Statistik Non parametrik. Jakarta : Penerbit PT.Elex Media Komputido Kelompok Gramedia.

Sarjunani, Nina .(2009)Rancangan RPJM Kesehatan .

Sediyaningsih E, R.(2009).Capaian Pembangunan Kesehatan. Kementerian Replik Indonesia.

Supriasa I Dewa Nyoman, dkk.(2002). Penilaian statis Gizi .Cet.I. Buku Kedokteran EGC : Jakarta.

Soekidjo,(2007). Pendidikan dan Perilaku Kesehatan. Jakarta : Kedokteran EGC.

Sujono. (2009). Manajemen Sumber Daya Manusia, Malang Universitas Muhammadiyah Malang.

Supanto,(2005). Peranan Keluarga dalam Pencegahan dan Penanggulangan Gizi Buruk.

Tarigan.(2003). Faktor - Faktor yang dihubungkan dengan penyebab dapat dibagi atas :

Yusuf,S.(2008).

Psikologi Perkembangan Anak: Bandung. Remaja Rosdakarya.

Yulianti. (2015). Penanggulangan Stunting \&Health, suatu Pendekatan Perubahan \& Peranan Gizi.jakarta Gramedia.

Muhtadi Deddy (2009). Pengantar Ilmu Gizi.: Bandung, ALFABETA

Riwayat Penulis :

Ana Samiatul M, SKM.,M.Mkes/ Nina Rosdiana,S.Kp.,M.Kep. Dosen Tetap Prodi Keperwatan Pada Yayasan Pendidikan Galuh (YPG), Fakultas Ilmu Kesehatan Universitas Galuh Ciamis. 